\title{
A union of values
}

Citation for published version (APA):

Bonelli, M. (2019). A union of values: safeguarding democracy, the rule of law and human rights in the EU member states. [Doctoral Thesis, Maastricht University]. ProefschriftMaken Maastricht. https://doi.org/10.26481/dis.20190619mb

Document status and date:

Published: 01/01/2019

DOI:

10.26481/dis.20190619mb

Document Version:

Publisher's PDF, also known as Version of record

\section{Please check the document version of this publication:}

- A submitted manuscript is the version of the article upon submission and before peer-review. There can be important differences between the submitted version and the official published version of record.

People interested in the research are advised to contact the author for the final version of the publication, or visit the DOI to the publisher's website.

- The final author version and the galley proof are versions of the publication after peer review.

- The final published version features the final layout of the paper including the volume, issue and page numbers.

Link to publication

\footnotetext{
General rights rights.

- You may freely distribute the URL identifying the publication in the public portal. please follow below link for the End User Agreement:

www.umlib.nl/taverne-license

Take down policy

If you believe that this document breaches copyright please contact us at:

repository@maastrichtuniversity.nl

providing details and we will investigate your claim.
}

Copyright and moral rights for the publications made accessible in the public portal are retained by the authors and/or other copyright owners and it is a condition of accessing publications that users recognise and abide by the legal requirements associated with these

- Users may download and print one copy of any publication from the public portal for the purpose of private study or research.

- You may not further distribute the material or use it for any profit-making activity or commercial gain

If the publication is distributed under the terms of Article $25 \mathrm{fa}$ of the Dutch Copyright Act, indicated by the "Taverne" license above, 


\section{Summary}

The cases of constitutional backsliding in Hungary and Poland, as well as other national threats to democracy, the rule of law and human rights, call for reflecting on how the EU can protect its founding values in the Member States. This is the main research question analysed in the book.

The first chapter explained how the European integration process has become associated with several political and constitutional values, and how this process of constitutionalisation transformed an economic project into a 'Union of Values'.

The second chapter then reflected on the content and meaning of these values at the EU level. Democracy, the rule of law and human rights are now affirmed in the Treaties and in the Charter, promoted in the enlargement and external policies of the Union, and further specified in EU secondary law. Yet, precise definitions and standards against which national policies can be assessed are not always precise.

The third chapter explained the legal framework and the normative reasons for values oversight at the EU level, arguing that EU institutions clearly have a mandate to intervene in case of national threats to common values, but the precise features of that mandate are not always clear and that the role of the EU is still contested. The chapter also identified some possible limits to EU intervention and concluded inter alia that the EU should not level out differences in national constitutional systems.

The fourth chapter of the book presented the main mechanisms EU institutions can use to protect the common values in the Member States: in the first place, Article 7 TEU, which should not be considered a nuclear option; but also infringement procedures and preliminary references, as well as softer monitoring instruments including the Commission Rule of Law Framework.

The fifth chapter then assessed how these mechanisms have been used in concrete instances in which EU values were under threat in the Member States. The chapter argued that the first reactions to the Hungarian and Polish crises were disappointing and ineffective; but more recent steps, namely the activation in both countries of Article $7(1)$ TEU and the opening of several infringement actions related to the independence of the judiciary or based on the Charter of Fundamental Rights, are more promising steps that can bring better results. Furthermore, the chapter looked at the EU's reaction to other, less severe threats to EU values and concluded that, despite some successful proactive approaches, the EU still lacks a comprehensive strategy to monitor national situations and intervene when necessary.

The sixth and final chapter of the book discussed, in the opening sections, current institutional and academic proposals to endow the EU with new mechanisms and procedures to protect EU values. It then contained some recommendations on how to improve the EU's toolkit, divided in two sections. First, the book argued that the EU should make better use of existing mechanisms, in particular exploiting the possibilities that Article 7, the Rule of Law Framework and infringement actions create. Furthermore, it should frame its intervention not only in terms of protecting the rule of law, but also using democratic and human rights arguments. Second, in the medium term, the EU should strive to better clarify democratic and rule of law standards, possibly by drafting 'Guidelines' also through comparative research; put in place a new monitoring framework, entrusted to the FRA; and reflect on the introduction of conditionality mechanisms and future reforms of the Article 7 TEU system. 